\title{
MOTIVASI KONSUMEN DALAM MELAKUKAN PEMBELANJAAN ONLINE DI KOTA BLITAR
}

\author{
Denok Wahyudi Setyo Rahayu ${ }^{1}$ \\ ${ }^{1}$ Fakultas Ekonomi Universitas Islam Balitar \\ email: ${ }^{1}$ denok.wahyudisr@gmail.com
}

\begin{tabular}{l}
\hline Kata kunci: \\
Persepsi \\
Motivasi konsumen \\
Pembelanjaaan online \\
Konsumen \\
\hline
\end{tabular}

\section{Keywords:}

Perception

Consumer motivation

Online shopping

Consumer

\section{Style APA dalam mensitasi artikel ini:}

Rahayu, D. W. S. (2021).

Motivasi Konsumen Dalam Melakukan Pembelanjaan Online Di Kota Blitar . Akuntabilitas: Jurnal Ilmiah Ilmu-Ilmu Ekonomi, 14 (2), $1-10$

\begin{abstract}
ABSTRAK
Pembelanjaan online akhir- akhir ini marak menjadi pilihan konsumen. Motivasi konsumen dalam melakukan pembelanjaan online antara lain faktor pengalaman, kepercayaan, kemudahan, harga, dan pengetahuan. Tujuan penelitian adalah untuk mengetahui faktor-faktor yang menjadi motivasi bagi konsumen dalam melakukan pembelanjaan online. Metode penelitian menggunakan pengamatan langsung dan kuisioner kepada para konsumen di Kota Blitar yang melakukan pembelanjan online. Populasi penelitian adalah konsumen belanja online di Kota Blitar. Teknik sampling menggunakan accidental sampling yaitu konsumen belanja online yang secara kebetulan bertemu dengan peneliti. Variabel yang digunakan adalah motivasi konsumen. Hasil penelitian menunjukkan bahwa motivasi konsumen dalam melakukan belanja online menunjukan hasil dalam bentuk prosentase bahwa responden cenderung memilih pengalaman dan kepercayaan (93,33\%), kemudahan $(90,00 \%)$, harga $(86,67 \%)$, dan dilanjut pengetahuan $(83,33 \%)$.
\end{abstract}

\section{ABSTRACT}

Online shopping has recently become a consumer choice. The motivation of consumers in making online purchases includes factors of experience, trust, convenience, price, and knowledge. The purpose of the study was to determine the factors that motivate consumers to make online purchases. The research method uses direct observation and questionnaires to consumers in Blitar City who make online purchases. The research population is online shopping consumers in Blitar City. The sampling technique uses accidental sampling, namely online shopping consumers who coincidentally meet with researchers. The variable used is consumer motivation. The results showed that consumer motivation in doing online shopping showed results in the form of a percentage that respondents tended to choose experience and trust (93.33\%), convenience $(90.00 \%)$, price $(86.67 \%)$, and continued knowledge $(83.33 \%)$. 


\section{PENDAHULUAN}

Aktivitas belanja menjadi hal yang tidak dapat dilepaskan dan melekat dalam kehidupan sehari-hari. Berbagai penawaran dilakukan oleh produsen untuk menarik minat beli konsumen. Keinginan minat beli merupakan sebuah perilaku (sikap) dari konsumen yang menginginkan untuk membeli atau menentukan pilihan dari suatu produk yang dapat berdasarkan pengalaman dalam memilih atau menentukan, serta menggunakan dan mengkonsumsi atau bahkan dalam menginginkan suatu produk yang ditawarkan oleh penjual (Kotler dan Keller, 2012 : 131). Adanya minat beli menjadi unsur penting pada terjualnya suatu produk. Munculnya minat beli dapat didasari oleh pengalaman baik secara pribadi maupun dari pihak lain yang merekomendasikan produk.

Pemasaran digunakan oleh produsen untuk menyampaikan produk yang dihasilkan kepada konsumen (Rahayu, 2019 : 46-57). Pemasaran yang baik akan mengarah ke keinginan belanja konsumen. Salah satu aktivitas belanja yang sedang marak saat ini adalah melalui pembelanjaan online. Pembelanjaan secara online akhirakhir ini menjadi pilihan para konsumen. Banyak kemudahan yang dijanjikan sehingga membuat konsumen cenderung tertarik untuk menggunakannya. Cara online tersebut banyak digunakan penjual atau produsen untuk meningkatkan penjualan dan minat beli konsumen.

Minat beli yang muncul dalam diri konsumen seringkali berada pada posisi berlawanan dengan kondisi keuangan yang dimiliki konsumen tersebut (Rizky dan Yasin, 2014). Kondisi minat beli terdorong karena adanya rasa tertarik konsumen terhadap produk yang ditawarkan. Semakin menarik produk kemungkinan akan memberi dampak positif terhadap penjulan produk.

Beragam aplikasi marketplace ditawarkan kepada konsumen. Marketplace dapat diartikan sebagai suatudepartment store dari onlineshop (accurate.id). Situs marketplace layaknya pihak ketiga yang menjadi tempat transaksi online yag menyediakan tampilan penjualan dan pembayaran untuk memberikan rasa aman bagi penjual dan pembeli. Produk yang ditampilkan pada marketpace kian beragam. 
Reputasi produk merupakan hal penting. Reputasi adalah akumulasi bukti keberhasilan layanan (Sidik, 2013). Keberadaan reputasi dapat menjadi salah satu pendorong minat beli. Reputasi yang baik dapat meningkatkan persepsi positif konsumen terhadap produk yang ditawarkan. Selain reputasi terdapat keyakinan dalam pembelanjaan online. Keyakinan konsumen dapat terbentuk berdasarkan tiga faktor yaitu : (1) faktor pengetahuan, (2) faktor pengalaman dan (3) faktor persepsi (Firdayanti, 2012). Lestari (2015) dalam penelitian yang berjudul "Shoping Online Sebagai Gaya Hidup" menyatakan yang mendasari aktivitas pembelanjaan online adalah segi budaya yang berperan dalam mengatur kehidupan seseorang; segi sosial dalam bentuk rekan lingkungan informan; segi personal berupa usia, pekerjaan, dan keadaan ekonomi; dan segi psikologis berupa motivasi atau dorongan dari pihak lain. Harahap (2018) menyatakan berdasarkan hasil penelitian bahwa perilaku atau sikap konsumen dalam melakukan belanja online di Indonesia dipengaruhi oleh faktor utama antara lain : (1) kepercayaan, (2) harga, (3) kenyamanan, (4) kemudahan dan (5) ketersediaan yang serta faktor lainnya seperti : keamanan, kualitas produk, website design dan perilaku konsumtif. Hardiyanto, dkk (2020) menjelaskan bahwa terdapat faktor-faktor yang menjadi pemahaman baru dalam model perilaku konsumen saat melakukan pembelanjaan online selama kondisi pandemic Covid-19 seperti : (1) kepercayaan, (2) kenyamanan, (3) kemudahan, dan (4) kemanan, serta adanya pemahaman mengenai perilaku pembelanjaan online oleh konsumen dari negara berkembang (Indonesia).

Kota Blitar merupakan wilayah yang menjadi sasaran penelitian. Di kota tersebut banyak konsumen yang melakukan pembelanjaan secara online. Konsumen memiliki bermacam persepsi (pemikiran) sebagai motivasi pembeli dalam melakukan pembelanjaan online. Permasalahan yang dikaji dalam penelitian adalah faktor-faktor yang menjadi motivasi bagi konsumen dalam melakukan pembelanjaan online. Batasan masalah penelitian pada alasan konsumen di wilayah Kota Blitar yang melakukan belanja online.

\section{METODE PENELITIAN}


Penelitian dilakukan pada bulan Agustus 2021 dengan lokasi di Kota Blitar. Populasi penelitian adalah masyarakat kota Blitar yang menggunakan aplikasi belanja online dan melalui media sosial whatsapp dengan teknik sampling dalam pengambilan sampel menggunakan accidental sampling yaitu subyek penelitian yang bertemu secara kebetulan bertemu dengan peneliti saat pelaksanaan penelitian. Sampel penelitian sebanyak 30 responden, yang mana Roscoe menyatakan ukuran sampel dapat dinyatakan layak berjumlah 30 sampai dengan 500 responden (Sugiyono, 2007:74).

Variabel penelitian yang digunakan adalah pembelanjaan online dengan indikator pengetahuan dan faktor pengalaman (Firdayanti, 2012); kepercayaan dan harga (Harahap, 2018), kemudahan (Hardiyanto, dkk, 2020). Indikator pengetahuan berupa sampai mana konsumen mengetahui produk (detail produk). Pengalaman merupakan pengalaman yang pernah dialami oleh konsumen terhadap produk yang pernah dibeli oleh konsumen. Kepecayaan sebagai tingkat percaya konsumen terhadap produk. Harga sebagai nominal nilai tukar produk. Kemudahan berupa seberapa mudah penggunaan belanja online.

Teknik pengambilan data dengan cara responden diminta untuk memilih faktor-faktor mana saja yang menjadi motivasi responden dalam melakukan pembelanjaan online dengan indikator pengetahuan, pengalaman, kepercayaan, harga, dan kemudahan. Faktor-faktor tersebut dapat dipilih semua atau beberapa indikator saja sesuai pilihan responden.

Teknis analisis data merupakan cara pengolahan data yang dilakukan berdasarkan hasil penelitian. Teknik analisis data yang digunakan untuk menganalisis adalah sebagai berikut :

(1) Tabulasi data hasil penelitian

(2) Prosentase Data Penelitian

(3) Penyajian data dalam bentuk diagram batang

(4) Pembahasan hasil penelitian 
Tabulasi data sebagai langkah pertama dalam pengelompokan data penelitian berdasarkan pilihan jawaban para responden. Prosentase data penelitian untuk melihat nilai prosentase data berupa kecenderungan jawaban responden. Diagram batang adalah diagram yang digunakan dalam analisis data untuk mengetahui pilihan jawaban responden yang tersaji dalam bentuk gambar berupa bentuk batang. Pembahasan hasil penelitian merupakan ulasan berdasarkan hasil penelitian dan dikaitkan dengan teori-teori serta hasil penelitian terdahulu.

\section{PEMBAHASAN}

Saat ini terdapat berbagai macam cara pemasaran. Pemasaran digunakan para produsen dalam menyalurkan atau memindahtangankan produk yang dihasilkan produsen kepada konsumen yang dituju (Rahayu, 2019 : 46-57). Salah satu kegiatan pemasaran yang sedang marak adalah belanja online. Kegiatan tersebut digunakan oleh produsen dalam menawarkan produknya melalui berbagai aplikasi yang tersedia saat ini. Penelitian yang dilakukan melalui teknik pengamatan dan wawancara diperoleh hasil sebagai berikut :

Tabel 1

Hasil Penelitian

\begin{tabular}{|c|l|c|}
\hline $\begin{array}{c}\text { Nomor } \\
\text { Pertanyaan }\end{array}$ & \multicolumn{1}{|c|}{ Indikator } & Responden \\
\hline 1. & Pengetahuan & 25 \\
\hline 2. & Pengalaman & 28 \\
\hline 3. & Kepercayaan & 28 \\
\hline 4. & Harga & 26 \\
\hline 5. & Kemudahan & 27 \\
\hline
\end{tabular}

Sumber : Data hasil Penelitian, diolah 2021.

Berdasarkan hasil penelitian, tabel 1 menunjukan bahwa responden selaku konsumen sebanyak 30 responden melakukan pembelanjaan online karena pengalaman (28 responden), kepercayaan (28 responden), kemudahan (27 
responden), harga (26 responden), dan pengetahuan (25 responden). Hal tersebut menunjukkan bahwa indikator pengalaman dan kepercayaan membawa peranan penting dalam pemilihan belanja online, dilanjut indikator kemudahan, harga, dan pengetahuan.

\section{Tabel 2}

Prosentase Data Penelitian

\begin{tabular}{|c|l|c|}
\hline $\begin{array}{c}\text { Nomor } \\
\text { Pertanyaan }\end{array}$ & \multicolumn{1}{|c|}{ Indikator } & Responden \\
\hline 1. & Pengetahuan & $83,33 \%$ \\
\hline 2. & Pengalaman & $93,33 \%$ \\
\hline 3. & Kepercayaan & $93,33 \%$ \\
\hline 4. & Harga & $86,67 \%$ \\
\hline 5. & Kemudahan & $90,00 \%$ \\
\hline
\end{tabular}

Sumber : Data hasil Penelitian, diolah 2021.

Tabel 2 menunjukan hasil dalam bentuk prosentase bahwa responden cenderung memilih pengalaman dan kepercayaan (93,33\%), kemudahan (90,00\%), harga $(86,67 \%)$, dan dilanjut pengetahuan $(83,33 \%)$. Berdasarkan tabel 2 tersebut dapat dinyatakan bahwa responden penelitian dalam memilih melakukan pembelajaan online cenderung karena faktor pengalaman dan kepercayaan, selanjutnya faktor kemudahan, kemudian faktor harga dan dilanjut faktor pengetahuan akan produk yang dibeli. 


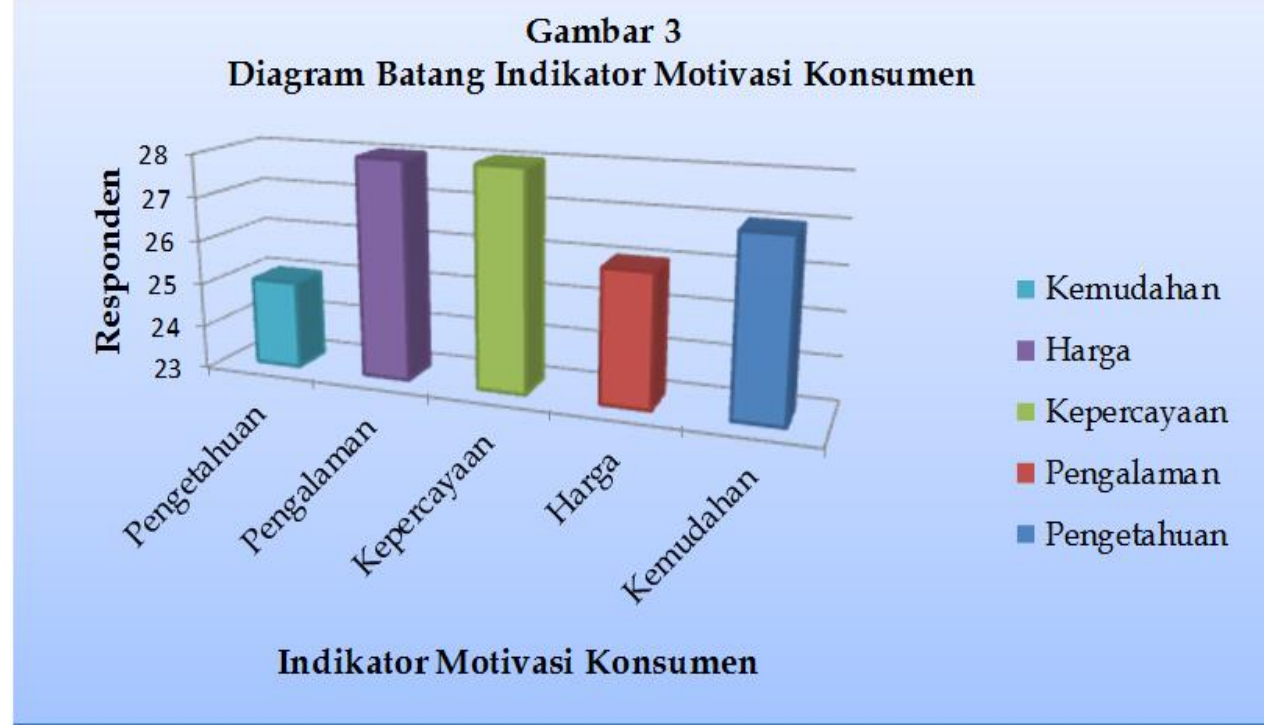

Sumber : Diagram Batang Indikator Motivasi Konsumen, diolah, 2021.

Gambar 3 menunjukkan hasil bahwa dalam pembelanjaan online responden selaku konsumen memilih indikator pengalaman dan kepercayaan dipilih oleh 28 responden, kemudahan 27 responden, harga 26 responden, dan pengetahuan (25 responden). Sehingga indkator pengalaman dan kepercayaan menjadi pilihan utama bagi konsumen.

Belanja online merupakan kegiatan belanja yang banyak diminati oleh konsumen akhir-akhir. Terdapat berbagai macam faktor pendukung yang membuat konsumen mau melakukan kegiatan tersebut. Berdasarkan hasil penelitian dari 30 konsumen selaku responden penelitian diperoleh data bahwa konsumen dalam melakukan belanja online dipengaruhi oleh faktor-faktor pengalaman dan kepercayaan, selanjutannya kemudahan, harga dan pengetahuan konsumen. Sehingga indikator pengalaman dan kepercayaan menjadi pilihan utama bagi konsumen.

Pengalaman dan kepercayaan menjadi faktor utama pilihan konsumen. Faktor-faktor tersebut terbentuk karena pembelanjaan online akan dilakukan oleh konsumen jika konsumen sudah berpengalaman baik pada produk yang akan dibeli. Selain itu, pengalaman menyenangkan yang diberikan penjual yang mengarah kepada rasa puas yang terbentuk dapat membuat konsumen memilih untuk melakukan pembelanjaan online kembali. Faktor pengalaman konsumen akan suatu 
kembali. Pengalaman tersebut berupa konsumen pernah melakukan pembelanjaan di situs tersebut dan konsumen pernah menggunakan produk tersebut. Hal tersebut yang membuat konsumen merasa yakin jika akan melakukan pembelanjaan online kembali.

Kepercayaan juga sebagai faktor pilihan utama disamping pengamalan. Konsumen jika melakukan pembelanjaan online berdasarkan atas rasa percaya konsumen terhadap penjual maupu produk yang akan dibeli. Rasa percaya tersebut dapat membuat konsumen merasa yakin dalam melakukan kegiatan pembelanjaan online.

Faktor kemudahan sebagai indikator selanjutnya pilihan konsumen. Kemudahan yang dimaksud adalah kemudahan konsumen dalam bertransaksi seperti berbagai macam metode pembayaran, pilihan produk, barang sampai di rumah dengan baik yang mana konsumen yang sibuk bekerja, tidak perlu keluar rumah namun barang langsung datang.

Harga pada barang online terkadang lebih murah. Bisanya penjual akan memberikan diskon atau potongan harga pada waktu tertentu seperti minimum belanja Rp 100.000,00 mendapat cashback 10\%, harga paket dengan nominal lebih murah dibanding satuan (misal : paket skincare isi 5 dijual Rp 200.000,00, namun jika satuan dapat menjadi lebih dari Rp 200.000,00), terdapat voucher dari situs belanja online.

Pengetahuan konsumen juga mendukung konsumen dalam melakukan belanja online. Konsumen yang memahami produk yang akan dibeli seperti kandungan produk, ukuran isi produk, dan lain-lain akan menyukai belanja online. Pengetahuan tersebut menjadi tolok ukur konsumen dalam memutuskan pembelian online. Pengetahuan akan produk membuat konsumen yakin akan keaslian dari produk yang akan dibeli. Konsumen telah mengetahui mana produk yang asli dan tidak. Tanda original yang tersaji pada display situs belanja online membuat konsumen merasa bahwa produk tersebut benar-benar bagus dan original atau asli. Spesisfikasi pada kotak deskripsi menambah keyakinan konsumen. 
Berdasarkan hal tersebut dapat diketahui bahwa konsumen cenderung menyukai belanja online. Hasil peneltian tersebut mendukung hasil penelitian dari Firdayanti (2012) mengenai kayakinan konsumen pada belanja online terbentuk oleh tiga faktor yaitu : faktor pengetahuan dan faktor pengalaman. Selanjutnya juga mendukung hasil penelitian dari Lestari (2015) yang menyatakan bahwa segi budaya yang berperan dalam mengatur kehidupan seseorang; segi sosial dalam bentuk rekan lingkungan informan; segi personal berupa usia, pekerjaan, dan keadaan ekonomi; dan segi psikologis berupa motivasi atau dorongan dari pihak lain. Demikian pula mendukung hasil penelitian Harahap (2018) mengenai kepercayaan, harga, kenyamanan, kemudahan, serta Hardiyanto, dkk (2020) mengenai kepercayaan, kenyamanan, kemudahan.

\section{KESIMPULAN}

Belanja online merupakan kegiatan belanja yang banyak diminati oleh konsumen. Kegiatan tersebut marak seiring waktu sehingga menjadi hal penting dan sering dilakukan karena adanya beberapa faktor penyebabnya. Faktor penyebab konsumen memilih melakukan belanja online adalah pengalaman yang pernah terjadi pada konsumen, kepercayaan dalam bentuk rasa percaya akan kondisi produk yang akan dibeli, , kemudahan dalam berbelanja seperti penggunaan berbagai macam metode pembayaran, harga yang cenderung lebih murah dan pengetahuan konsumen akan produk yang akan dibeli. . Faktor tersebut membuat konsumen merasa lebih nyaman dalam melakukan pembelanjaan online.

Selain itu menurut konsumen terdapat nilai kurang dari belanja online, terkadang foto yang ditampilkan bukan produk sebenarnya. Selain itu, terkadang apa yang diterima konsumen tidak sesuai dengan yang ditampilkan di situs. Hal tersebut terjadi karena terkadang penjual menggunakan foto lain untuk ditampilkan dalam situs belanja online, sehingga konsumen beranggapan foto tersebut adalah produk yang akan diterima. Hal tersebut dapat menjadi kajian bagi penelitian selanjutnya. 


\section{DAFTAR PUSTAKA}

\section{https://accurate.id/marketing-manajemen/apa-itu-marketplace/}

Firdayanti, R. (2012). Persepsi Risiko Melakukan E-Commerce Dengan Kepercayaan Konsumen Dalam Membeli Produk Fashion Online. Journal of Social and Industrial Psychology. 1 (1): 1-7.

Harahap, DA. (2018). Perilaku Belanja Online Di Indonesia: Studi Kasus. Jurnal Riset Manajemen Sains Indonesia (JRMSI). 9 (2) : 193 - 213.

Hardiyanto, N, dkk. (2020). Analisis Perilaku Belanja Online Selama Masa Pandemi COVID-19.Jurnal Riset Bisnis dan Investasi, 6(3):120-130.

Kotler, Philip Dan Kevin Lane Keller. (2012). Marketing Management 13. New Jersey: Pearson Prentice Hall, Inc.

Lestari, Sri Budi. (2015). Shopping Online Sebagai Gaya Hidup. Jurnal Ilmu Sosial. $14(2): 24-41$.

Rahayu, DWS. (2019). Efektifitas promosi Dalam Peningkatan Penjualan Produk Kosmetik Di Kota Bitar. Akuntabilitas: Jurnal Ilmu-Ilmu Ekonomi, 12 (1) : 46-57.

Rizky, M. F., \& Yasin, H. (2014). Pengaruh Promosi Dan Harga Terhadap Minat Beli Perumahan Obama PT. Nailah Adi Kurnia Sei Mencirim Medan. Jurnal Manajemen \& Bisnis, 14(02) : 135-143.

Sidik, I. G. (2013). BISNIS SUKSES: Menyusun Rencana Bisnis Lengkap Terpadu. Jakarta: Gramedia Pustaka Utama.

Sugiyono. (2007). Metode Penelitian Kuantitatif, Kualitatif dan RED. Bandung : Alfabeta. 